\title{
DEVELOPMENTS
}

\section{The Case of Laval in the Context of the Post-Enlargement EC Law Development}

\author{
Uladzislau Belavusau*
}

\section{A. Introduction}

This article does not envisage an overwhelming goal to present a detailed X-ray of the recently much-discussed ECJ decisions in the field of social law, namely Laval ${ }^{1}$ and Viking ${ }^{2}$. One could find several very profound papers whose authors thoroughly explore the various issues at stake, including the trade unions strategies in the frame of the EC Law, the role of the Posted Workers Directive, a horizontal direct effect in the context of the service-providing, the negotiation of wages and the Scandinavian social model. ${ }^{3}$ Therefore, the goal of this piece is to put Laval ${ }^{4}$ into

\footnotetext{
* Ph.D. Researcher at the European University Institute (Florence, Italy), LL.M. from Collège d'Europe (Bruges, Belgium). I owe a particular gratitude to Professor Marie-Ange Moreau for feedback and suggestions and to Professor Jenö Czuczai for a detailed discussion of the arguments. The usual disclaimer applies. Email: Uladzislau.Belavusau@EUI..eu

${ }^{1}$ Case 341/05, Laval un Partneri Ptd v. v Svenska Byggnadsarbetareförbundet et al., 2007 ECR I-5751. The case is often referred to as Vaxholm case because the industrial action was undertaken on a building site in Vaxholm, a town not far from Stockholm (see Kerstin Ahlberg, Niklas Bruun, and Jonas Malmberg, The Vaxholm Case from a Swedish and European Perspective, 12 TRANSFER 2/06, 155, 155-166 (2006).

2 Case 438/05, International Transport Workers' Union Federation et al. v. Vikingline ABP et al., 2007 ECR I000 .

${ }^{3}$ See for example, Norbert Reich, Free Movement v. Social Rights in an Enlarged Union - the Laval and Viking Cases before the ECJ, 2 GLJ, 125, 125-161 (2008); Bruno Mestre, The Ruling Laval un Partneri: Clarification and Innovation, 1 ELR, 2, 2-9 (2008); Brian Bercusson, The Trade Union Movement and the European Union: Judgement Day, 13 ELJ, 279, 279-308 (2007); Patrick Chaumette, Les actions collectives syndicales dans le maillage des libertés communautaires des enterprises, 2 OBS. SUR CJCE, DR. SOC., 210, 210-220 (2008).

${ }^{4}$ The focus of this paper is on Laval due to the fact that in Viking the ECJ offered a less articulated feedback on the status of social provisions. In Viking, the Luxembourg jury leaves it to the national courts to decide on the outcomes. Besides, the issue of the flag of convenience would need a separate thorough analysis in the context of Private International Law, especially with the implications for the taxation system.
} 
the macroflora of a wider context, inherent to the effects of the post-enlargement labour conflict and its implications for the fundamentalization of social rights in the Union.

One of the most delicate issues which the eastward enlargement brought into the EU agenda has become the discussion on the modifications in the regulation of labour market in the EU-25 (or EU-27 after 1 ${ }^{\text {st }}$ of January, 2007). The majority of preaccession commentators (including economists, political scientists, journalists as well as lawyers) focused on the quantitative analysis of the enlargement implications, i.e. on the potential influx of workers from Central and Eastern Europe (referred to below as - EU-10, or CEEC). This approach echoes a particular concern of certain old member states (referred to below as - EU-15) about the protection of national labour markets vis-à-vis the newcomers.

Michael Dougan named three 'potentially adverse consequences' for the existing member states in his remarkable 'pre-accession' articles: "That the enlargement might lead to large-scale benefit migration towards western countries which have established generous welfare systems; that a massive influx of workers from the CEEC would seriously disrupt labor markets in the EU-15; that difference between wages and other compliances costs might lead to social dumping in favor of undertakings from the CEEC" ${ }^{6}$

Since, on the one hand, initially only three countries from the EU-15 opened their labor markets to the newcomers, and on the other hand, the post-accession reality in those three countries demonstrates that first two fears did not check out ${ }^{7}$, the increasing concern is being raised towards the problem of social dumping ${ }^{8}$. The

${ }^{5}$ Michael Dougan, A Spectre is Haunting Europe...Free movement of Persons and the Eastern Enlargement, in EU ENLARGEMENT: A LegAl APPROACH, 111-142 (Christophe Hillion, ed., 2004).

${ }^{6} I d ., 112$.

7 Nicola Doyle, Gerard Hughes and Eskie Wadensjo, Freedom of Movement for Workers from Central and Eastern Europe: Experiences in Ireland and Sweden, 5 SWEDISH INSTITUTE FOR EUROPEAN POLICY STUDIES (2006).

8 The notion of 'social dumping' will be analyzed with regard to the EC Social Law. It is a theoretical construction which is described neither in EC \EU Treaties, nor sufficiently defined in the case-law. In the enlargement context the term 'dumping' is often referred to describe the influx of cheep goods on the EU-15 market. See PAUl BRENTON, ANTI-DUMPING, DIVERSION AND THE NEXT ENLARGEMENT OF THE EU (1999). In Laval both the Advocate General in his opinion and the Court in its decision address the notion of social dumping on several occasions without setting a general definition (For further discussion, see especially para. 103, 113 in the decision; see also numerous references to the "combat of social dumping" in the Opinion of AG Mengozzi: para. 246, 249, 251, 273, 280, 307, 309). The anti-dumping measure is interpreted strictly in the context of the Swedish Law on Workers' Participation in Decisions 
latter is proved by the discussion around the long-awaited pronouncements of the ECJ in Laval and Viking, and has acquired a deep resonance both in media ${ }^{9}$ and legal literature ${ }^{10}$. The decision in Laval is acute precisely due to the popular expectation (realistic or not) that it sheds light on whether social standards could serve as appropriate derogations under internal market, analogous to the derogations developed by the ECJ to safeguard fundamental rights.

\section{Brief Facts:}

A Latvian construction company Laval accused a Swedish trade union of forcing it out of business after the industrial action aimed at enforcing the Latvian company to conclude a collective agreement. This turned to be a real blockage by the Swedish Building Workers' Union supported by the Electricians' Union through a secondary action. Sweden did transpose the Posted Workers Directive however it did not set a national minimum wage, relying instead on collective pay agreements arranged by the country's powerful trade unions. By paying the Latvian workers almost two times less the average wage for similar construction jobs done by the Swedish workers (average-salary-calculation-scheme), the Latvian company was arguably capable of undermining Swedish social standards.

One should bear in mind that for the purposes of this paper, 'economic freedoms' shall not be read in conjunction with 'social freedoms' in a way to establish a legal fiction of 'economic and social rights' traditionally referred to in juridical literature with an accent on the rights of workers. ${ }^{11}$ Hereby 'economic freedoms ${ }^{\prime 12}$ are used to

(Medbestammändelagen). Further the paper will attempt to find, at least, an adequate description of social dumping in the post-enlargement context.

${ }^{9}$ Michael Herman and Agencies, ECJ hears landmark labor case, TIMES ON-LINE (9 January 2007). Available at: http://business.timesonline.co.uk/tol/business/law/corporate/article1291012.ece (last accessed on 18 November 2008); Nikki Tait, A Viking sea battle to rock the EU boat, THE FINANCIAL TIMES (1 January 2007). Available at: http://us.ft.com/ftgateway/superpage.ft?news_id=fto010120071237549438 (last accessed on 18 November 2008).

10 See further, Gorce Gaëtan, L'Union européenne face aux risques de dumping social, 7 ASSEMBLE NATIONALE, 2000; Ronnie Eklund, The Laval Case. Swedish Labour Court Decision 2005 No. 49, 35 ILJ 203 (2006).

${ }^{11}$ For an example, see TAMARA K. Hervey AND JeFF KENNER, ECONOMIC AND SOCIAL RightS UNDER THE EU Charter of Fundamental rights: a Legal Perspective (2003); MattheW C.R. Craven, The INTERNATIONAL COVENANT ON ECONOMIC, SOCIAL, AND CULTURAL RIGHTS: A PERSPECTIVE ON ITS DEVELOPMENT, (1995).

${ }^{12}$ When these rights referred to in the literature as 'fundamental rights' (les droits fondamentaux), it is usually done with the aim to distinguish them from the 'fundamental freedoms' (les libertés fondamentales). Within this approach the former are meant to be synonymic with human rights. And the latter are those which come under the scope of internal market. See in particular, Alberto Alemanno, $A$ la recherche d'un juste équilibre entre libertés fondamentales et droits fondamentaux dans le cadre du marché 
describe the provisions of the EC internal market covering free movement of workers (Article $39 \mathrm{EC}$ ), freedom of establishment (Article $43 \mathrm{EC}$ ) and freedom to provide services (Article $49 \mathrm{EC}$ ). The terms 'human rights' and 'fundamental rights' are used synonymously. ${ }^{13}$

The first part of this article will address the evolution of the relevant internal market provisions and social law with a separate accent on the effect of previous enlargements. The second part will put Laval into the realm of fundamental rights in the Union. The attention will be focused on the pre-enlargement debate and labour safeguards negotiated before the enlargement. The conclusions will try to identify the degree to which Laval is an indicator of the fundamentalization of social rights.

\section{B. Laval in the Context of the Internal Market}

\section{Evolution of the Internal Market through a Social Dimension}

Three pivotal EC Treaty provisions concerned, namely Article 39 EC (free movement of workers), Article 43 EC (freedom of establishment) and Article 49 EC (freedom to provide services), are to be discussed in conjunction with each other and within a larger-scale debate on the free movement of persons. ${ }^{14}$ Nonetheless, one should bear in mind that the case-law approach towards those particular freedoms is not identical and a profound detachment is required when discussing the scope of Treaty clauses. E.g., Article 39 EC embraces exclusively natural persons

intérieur: Quelques réflecions à propos des arrêts «Schmidberger » et « Omega » », 4 Revue du droit de l'Union européenne [RDUE] 709 (2004).

13 This synonymous approach has become traditional for EC law doctrine; in particular, see Armin Von Bogdany, The European Union as a Human Rights Organization? Human Rights and the Core of the European Union, 37 CML REV. 1307, 1307-1338 (2000). It should be noted that sometimes the terminology of 'fundamental rights' is used to embrace even a wider scope of rights and freedoms, including civil, cultural, economic, social and political rights (For an example, see John Morijn, Balancing Fundamental Rights and Common Market Freedoms in Union Law: Schmidberger and Omega in the Light of the European Constitution, 12 ELJ 15, 15-40 (2006) which is inadmissible in the light of the present paper, since it distinguishes 'fundamental' (human) and 'social' rights in order to answer the question whether the latter has acquired (or might acquire) a similar 'derogation' status which human rights do enjoy now in EC law.

${ }^{14}$ For a more comprehensive analysis see CATHERINE BARNARD, THE SUBSTANTIVE LAW OF THE EU: THE FOUR FREEDOMS (2006); ROBIN C.A. WHITE, WORKERS, ESTABLISHMENT AND SERVICES IN THE EUROPEAN UNION (2004). 
whereas Article $43 \mathrm{EC}$ is also applicable to companies..$^{15}$ Despite all differences, these provisions are interpreted in a very similar way since the development of EC Law on the case-by-case basis has led to the approximation of conditions of entry, residence and expulsion for all EU nationals. ${ }^{16}$ This stance also had implications on the family rights of workers and the standardisation of access to social benefits. ${ }^{17}$ Thus, a trendy approach in legal literature is to describe these rights within a wider notion of the right to pursue an occupation in another Member State. ${ }^{18}$

\section{Genesis and Evolution}

The genetic core of the pursuit of occupation is embraced by the legal matrix of free movement of persons. Similarly to the domain of free movement of goods, it was the ECJ who has been incubating this specific legal ground for European mobility. Fifty years of European judicial-making involved the controversy on refusal of entry and deportation, theoretical delimitation of direct and indirect discrimination as well as a rigid application of the principle of proportionality. ${ }^{19}$ The latter permitted the Court to prevent an abusive interpretation of derogations under public policy by particular member states. Fundamental human rights served as an argument in safeguarding broad scope of the right to move freely within the European Community. ${ }^{20}$ This genetic ('free movement of persons') approach finds its extension in a very wide judicial definition of a worker as well as of the rights conferred on workers by EC Law (the rights to depart the home state, the right to enter the host state and the right of residence in the host state). Furthermore, with regard to workers the Court continued to define employment and family rights within the concept of equal treatment though significantly narrowing their scope in

\footnotetext{
${ }^{15}$ For a more detailed distinguishing analysis between workers and services providers in the context of free movement see Marc De Vos, Free Movement of Workers, Free Movement of Services and the Posted Workers Directive: a Bermuda Triangle for National Labour Standards? ERA-Forum, N 3/2006, 357, 357-359 (2006).

${ }^{16}$ EUROPEAN Union LaW: TEXTS AND MATERIALs, 705 (DAMIAN CHALMERS ED. 2006)

17 Consider Case 85/96, Martinez Sala, 1998 ECR 1-2691; Case 314/99, Baumbast, 2002 ECR I-07091; Case 60/00, Carpenter, 2002 ECR I-6279; Case 148/02, Garcia Avello, 2003 ECR I-11613; Case 200/02, Chen, 2004 ECR I-09925.

${ }_{18}$ Chalmers, supra note 16, 697.

19 Florence Hartmann-Vareilles and María Pilar Nunez Ruiz, «Le travailleur communautaire: quelques réflexions sur un élément inachevé du marché intérieur », ERA, 3/2006 326, 326-344 (2006).

${ }^{20}$ Consider Case 168/91, Konstantinidis, 1993ECR 1-1191; Joint Cases 493/01 and C-482/01, Orfanopulos, 2004 ECR I-05257; Case 109/01, Arkich, 2003 ECR I-09607.
} 
comparison with the rights of European citizens to move for the purposes of tourism, study or exercise of medical services. ${ }^{21}$

Another legal paradox in the genesis of the European labour market is that freedom of movement was initially introduced in the Treaty for the specific categories of economically active people. One could hardly expect that ECJ would extend this doctrine so far as to stretch the pre-existing notions ${ }^{22}$ towards such categories as students ${ }^{23}$ and other non-economic actors ${ }^{24}$. On the other hand, the notion of economic activity ${ }^{25}$ received a very broad interpretation in case practice. ${ }^{26}$ Even sport was acknowledged as a subject of community law since sportsmen could exercise economic activities. ${ }^{27}$ The Court rejected attempts by the Member States to extend Keck formula ${ }^{28}$ beyond the limited scope pertinent to the free movement of goods. It is no accident that the free movement of persons has now become a major motor of integration.

Thus, the choice of the Court in Laval was either to keep in line with the logic of the maximum safeguard of the economic freedoms or to frame "social rights" into the list of the essential derogations for the internal market. It seems like the ECJ has decided to stay perfectly in line with its systematic refusal to interpret derogations

\footnotetext{
${ }^{21}$ See Pedro Cabral, La libre cirulation des soins médicaux dans l'Union européene, Sean Van Raepenbusch, Libre circulation et sécurité sociale, and Pablo Dengler, Libre circulation des personnes et imposition dircte, in LA LIBRE CIRCULATION DES PERSONNES : ETATS DES LIEUX ET PERSPECTIVES, CAHIERS DU COLLEGE D'EUROPE Nº 5, ACTES D’UN COLLOQUE ORGANISE EN 2003 A LIEGE (2007), 203-268.

${ }^{22}$ Francesca Strumia, Citizenship and free movement: European and American features of a Judicial Formula for Increased Comity, (2006) CJEL, Vol. 12, 3/2006. 714-715.

${ }^{23}$ Case 209/03, Bidar, 2005 ECR I-02119 (para. 83).

${ }^{24}$ Case 200/02, Chen, 2004 ECR I-09925.

25 Interestingly enough, in his Opinion in Case C-96/04, Standesamt Stadt Niebull (name of LeonhardMatthias) AG F. Jacobs goes even further to admit that one should not look for economic actor any longer.

26 The Court even found the link between economic activities and the language (Case 281/98, Angonese, [2000] ECR I-4139; Case 378/87, Groener, 1989 ECR I-3967 etc) or between economic activities and the name (Konstantinidis, supra note 21, Garcia Avello, supra note 18, 2003 ECR). Moreover, the prostitution was acknowledged being an economic activity (Joined Cases 115 and 116/81, Adoui \& Cornuaille, 1982 ECR I-1665).

${ }^{27}$ Case 415/93, Bosman, 1995 ECR I-4921.

${ }^{28}$ Cases 267/91 and 268/91, Keck \& Mithouard, 1993ECR 1993 I-06097.
} 
widely. ${ }^{29}$ Further we shall see whether this stance could have been informed by the deliberation at the particular post-enlargement context.

\section{The Potential in the Light of the EU Citizenship}

The very project of European citizenship is rather young though the discussion traces back to the early 1970s. ${ }^{30}$ The notion of EU citizenship was introduced to acquis only in 1992 by the Maastricht Treaty and provoked a hearty debate in the milieu of European lawyers on the differences in the perception of this ambiguous term. The debate went on to analyze whether EU citizenship is supplementary to national one. This debate has asked whether the introduction of 'citizenship' towards the basic instruments of the EU as a supranational organization leads to the creation of European demos and what effects it may have for national folks. ${ }^{31}$ The debate has also looked at whether that legal model should be perceived as a market citizenship (focusing on the rights of economic actors), social citizenship (emphasizing the social-welfare elements of citizenship), or a republican citizenship (based on an active citizen participation). ${ }^{32}$

Finding an answer to these open questions is an on-going task for the ECJ. Thus, in a series of student cases $^{33}$ the Court introduces the idea that EU citizenship is "destined to be the fundamental status". ${ }^{34}$ In fact, the Court gives the projection into the future without regard for the reality of the moment. This is a remarkable

${ }^{29}$ Para. 98: "[...] The abolition, as between Member States, of obstacles to the freedom to provide services would be compromised in the abolition of State barriers could be neutralised by obstacles resulting from the exercise of their legal autonomy by associations or organizations not governed by public law".

${ }^{30}$ This notion was first introduced in the German legal doctrine in the 1960s. For an analysis of the evolution of the term see Dominik Hanf, Le développement de la citoyenneté de l'Union européenne , in LA LIBRE CIRCULATION DES PERSONNES : ETATS DES LIEUX ET PERSPECTIVES, CAHIERS DU COLLEGE D'EUROPE N5, ACTES D’UN COLLOQUE ORGANISE EN 2003 A LIEGE, (2007), 16-17.

31 Joseph H.H. Weiler, Does Europe Need a Constitution? Reflections on Demos, Telos and the German Maastricht Decision, ELJ 219 (1995).

32 BARNARD, supra note 14, 402-403.

${ }_{33}$ Case 293/83, Gravier, 1985 ECR I-00593; Case 184/99, Grzelczyk, 2001 ECR I-07091; Case 209/03, Bidar, 2005 ECR I-02119. M.ichael Dougan, The Constitutional Dimension to the Case Law on Union citizenship 31 E.L. REV. 613 (2006).

${ }^{34}$ Grzelczyk, supra note 34, 2001 at para. 31. See also an unusual (in terms of legal rhetoric) recent Opinion of AG Colomer in Joint Cases 11/06 and 12/06, Rhiannon Morgan v Bezirksregierung Koln and Iris Bucher v Landrat des Kreises Duren, 2007 (para. 37-68), where he refers to historical aspects of this particular destiny of European citizenship. 
statement since the Court did not word it like "supplemental to fundamental". The way the Court phrases this idea reveals certain evolutional and even constitutional implications, setting a road map (indication de voies) for the future of European integration. In this respect, the essential conflict in Laval (which brings the jury into the new reality of the EU-27) fitted the case-line with a quasi-constitutional potential.

What is even more interesting in the context of transition upon recent enlargements is whether 'social citizenship' is an appropriate construction to describe a legal phenomenon of a supranational EU citizenship. If so, does this approach have consequences for the internal market of the EU-27? Moreover, whether this 'EU citizenship' approach has implications for the freedom of establishment and services, i.e. whether it embraces a new perception of legal entities in EC Law is another question to consider. There is a danger that companies could perceive this legal incentive in a way to simplify their conduct of business through evading local company law and tax law requirements. The latter would provoke an overflow of capital to Member States with a less onerous regime. ${ }^{35}$ The judgement in Kaba ${ }^{36}$ with regard to individuals demonstrates limitations of Community law on citizen's right to free movement and residence though no clear criteria are established so far to limit the influx of non-economic actors to generous welfare states. ${ }^{37}$ Finally, the solidarity is another notion, which is to be interpreted in conjunction with citizenship. ${ }^{38}$

When analyzing Laval, one should bear in mind that the decision is taken in the specific post-enlargement context, where the Court is expected to rule not just on the legitimacy of the way some country is transposing the EU legislation (the question of the "minimum wages" avoidance in Sweden, stemming from the Posted Workers Directive), but to shed light onto the status of the internal market for the ever biggest EU citizenship. Interestingly enough, the vocabulary of the Luxembourg judges carefully avoids any references to the enlargement context in this case. The sanctuary of the internal market cannot afford those enlargement connotations. The Court avoids the risk of bringing the political debate on the

\footnotetext{
${ }^{35}$ Barnard, supra note 14, 402-403.

${ }^{36}$ Case 356/98, Kaba I, 2000 ECR I-2623 and Case 466/00, Kaba II, 2003 ECR I-2219.

${ }^{37}$ Dougan, supra note 6, 114 .

38 The question of 'European solidarity' has been profoundly treated in a series of European Law Review: Editorial, The unbearable heaviness of European citizenship, 31 E.L. REV. (2006). Also, Oxana Golynker Jobseekers' rights in the EU: challenges of changing the paradigm of social solidarity, 30 E.L.REV., 111, 111-123 (2005).
} 
necessity of the affirmative support for the newcomers into the text of its decision. The leitmotif of the pure case-law-sufficient-derogations-test (which the Swedish legislature failed to pass) declines the incentives to discuss the fragmentation of the European citizenship due to the danger of social dumping. Such delicate wording is particularly important taking into account the safeguard restrictions on the working markets negotiated before the enlargement.

\section{Social dumping as a Phenomenon of Previous Enlargements}

\section{Scope of the Problem}

There exist a number of factors that might encourage a process of social dumping within the enlarged EU ${ }^{39}$ : labour mobility; labour costs; employer's cost burden and then different welfare standards in terms of a minimum wage and a rest period; minimum workplace safety; health standards; and non-discrimination measures. The question then to be posed is whether the exercise of labour competition is fraught with a temptation for the enterprises and individual workers to seek better employment opportunities abroad ${ }^{40}$ and thus, is able to provoke a social dumping through the indirect lowering of wages and labour standards in the countries with traditionally more generous wages. Thus, the notion of social dumping with regard to workers and services could be arguably compared to 'welfare tourism' in the context of free movement of persons. Three factors which need to be taken into consideration when speaking about the risks of social dumping are as follows: the price of work, regulation of work and the role of social partners. ${ }^{41}$ Interestingly enough, there is evidence that during the last twenty years certain states, in agreement with social partners, deliberately practiced policy of salary moderation in order to acquire a competitive advantage (e.g., the Netherlands, Finland and Ireland). This approach permitted them to accumulate extra benefits and significantly reduce their unemployment rate. ${ }^{42}$

\footnotetext{
${ }^{39}$ Further enumeration is based on the article of Prof. Dougan, supra note 5.

${ }^{40} \mathrm{Id} ., 7$.

${ }^{41} I d ., 17$.

${ }^{42} I d$.
} 


\section{Case Law Upon the Enlargement(s)}

In the seminal ${ }^{43}$ case of Rush Portuguesa ${ }^{44}$ the ECJ faced the dilemma for the first time upon the accession of Portugal and Spain to the EC. The accession instrument foresaw a transitional phase for the free movement of workers though did not preview any derogation for the movement of services. A Portuguese construction company tried to benefit from this situation and offered its services simultaneously bringing cheap Portuguese labour force into the French construction market.

The decision of the Court is quite ambiguous. On the one hand, the ECJ took a rather defensive position with regard to safeguarding internal market upon the enlargement and ruled that the Portuguese company had to perform services in the host country under the same conditions as imposed by that state on its own nationals. On the other hand, in Paragraph 18 of the judgement ECJ made a revolutionary statement that Community Law does not preclude Member States from extending their labour legislation and collective labour agreements to "any person who is employed, even temporarily, within their territory". ${ }^{45}$ Thus, the effect of the Court dictum is astonishing since it permitted to impose national labour regulations on foreign service providers even though their temporarily post workers could not be regarded as host country's workers. ${ }^{46}$ This approach found its enforcement in the so-called Posted Workers Directive ${ }^{47}$ which turned this mechanism to extend national regulation from a mere possibility into an essential requirement. The Posted Workers Directive gives a certain discretion to host states vis-à-vis posted workers in establishing minimum wages, working time and equal treatment. ${ }^{48}$ Further in Laval the Court will face the problem of the imposition of the Posted Workers Directive into the Swedish legislation where the regulation of the

\footnotetext{
${ }^{43}$ De Vos, supra note 15,361 .

${ }^{44}$ Case 113/89, Rush Portuguesa v. Office national d'immigration, 1990 ECR I-1417.

${ }^{45} I d .$, para. 18.

${ }^{46}$ De Vos, supra note 15, 362. See also Markus Kahmann, The posting of workers in the German construction industry: responses and problems of trade union action and Bruno Lefebvre, Posted workers in France, 12 TRANSFER 183-196, 197-212 (2006).
}

${ }^{47}$ EC Directive 1996/71 of the European Parliament and of the Council, of 16 December 1996, concerning the posting of workers in the framework of the provision of services, O.J. L18/1.

${ }^{48}$ CATHERINe BARNARD, EC EMPlOYMENT LAW, Third Edition, 278 (2007). See also Olaf Deinert, Posting of Workers to Germany: Previous Evolutions and New Influences Throughout EU Legislation Proposals, 16 INT. J. COMP. L.L.I.R. 217-234 (2000) 
"minimum wages" is traditionally avoided. It is the matter of labour bargaining with the trade unions. ${ }^{49}$

In a series of 'German' cases it appeared that the Court took a protective stance with regard to the workers from Southern and Eastern Europe enjoying benefits from a particular regulation of the labour conditions for temporary staff being adjudicated to the rules and conditions of the home country. ${ }^{50}$ In the recent edition of her book, Catherine Barnard identifies the four-stage test applied by the Court in the subsequent case law. ${ }^{51}$ The Court analyzes (1) whether there is a restriction on the freedom to provide services, (2) whether a justification could be applied (worker protection, interests of the posted workers), (3) whether the same interest is already protected in the home country, and finally (4) whether the measure could be regarded as proportionate. ${ }^{52}$ Thus, in Mazzoleni $i^{53}$ the Court finds that Belgian authorities imposed on posted workers a minimum wages measure which is evidently disproportionate since the application of Belgian law to service providers in the frontier region could result in an extra administrative burden to individual service provider, including a complicated system of an hour-by-hour wage calculation upon each crossing of the border and threat to good working relations within a particular undertaking. ${ }^{54}$ The same four-stage test is applied in Laval, where the court finds a complicated system of wage negotiation with trade unions in Sweden to be disproportionate as it actually contradicts the logic of minimum wages, inherited to the Posted Workers Directive. 55

\footnotetext{
${ }^{49}$ For a comprehensive analysis see Reich, supra note 3.

${ }^{50}$ Case 43/93, Vander Elst v. Office des Migrations Internationales, 1994 ECR I-3803. See also Case 244/04, Commission v. Germany, 2006 ECR I-000. The reference should be made to the rules of Rome Convention on rules concerning the law applicable to contractual obligations OJ 1980 L266/1.

${ }^{51}$ BARNARD, supra note 48, 278-280.

52 Id., 278.

53 Case 165/98, Criminal proceedings against André Mazzoleni and Inter Surveillance Assistance SARL, 2001 ECR I-2189.

${ }_{54}$ BARNARD, supra note 48, 279. See also Jean-Philippe Lhernould, Le principe de non-discrimination à l'égard des frontaliers en matière de sécurité sociale, ERA, 3/2006 381 (2006). The author provides an analysis of the specific rules of coordination in the fields of social security applicable to frontier workers.

${ }^{55}$ In fact, in para. 103 of Laval the Court directly refers to Mazzoleni, so the "internal market reasoning" of the ECJ seems to be quite consistent.
} 
In Finalarte ${ }^{56}$ the Court held that the construction companies based in the UK and Portugal who posted workers to Germany should adhere to the 'holiday standards' of Germany even if the number of holidays exceeds the four weeks' paid leave fixed in the Working Time Directive 2003/88.57 Although this measure is in breach of the internal market, it is still proportionate. In Portugaia Construções ${ }^{58}$ the Court ruled that the measure to reduce the allegedly unfair competitive wages was, in itself, incapable of constituting a "valid imperative requirement due to its protectionist economic nature".59 In Commission v. Luxembourg60 the Court found proportionate the measure which required a service provider to report in advance on the presence of posted worker(-s), the anticipated duration of this presence and justification of the deployment. However, in this line of cases the Court took a very negative view on the requirement of establishing minimum employment time ${ }^{61}$, granting individual work permits only if labour situation was favourable enough ${ }^{62}$, securing bank guarantee to cover costs in case a worker comes back home and licensing posted work ${ }^{63}$.

In Laval the Court accepts that "social dumping may constitute an overriding reason of public interest within the meaning of the case-law of the Court which, in principle, justifies a restriction of one of the fundamental freedoms guaranteed by the Treaty" 64 and further refers to the case-law upon previous enlargements to support its view. ${ }^{65}$ Hence, although it does not frame social derogations into the "fundamental rights exception", the Court nevertheless leaves an essential potential for the fundamentalization of social rights in the future, similar to the one in the seminal case of Rush Portuguesa.

\footnotetext{
${ }^{56}$ Case 68-71/98, Finalarte, 2001 ECR I-7831.

57 EC Directive 93/104 of the Council, of 23 November 1993, concerning certain aspects of the organisation of working time, OJ L 307.

${ }^{58}$ Case 164/99, Portugaia Construções, 2002 ECR I-787.

${ }^{59}$ Dougan, supra note 5, 137.

${ }^{60}$ Case 445/03, Commission v. Luxembourg, 2004 ECR I-10191.

${ }^{61}$ Commission v. Luxembourg, 2004 supra note 60, and, Commission v. Germany, 2006, supra note 50.

${ }^{62}$ Commission v. Luxembourg, 2004 supra note 60, and, Vander Elst, 1994, supra note 50.

${ }^{63} I d .$, para. 30 and 47.

${ }^{64}$ Para. 103.

${ }^{65}$ In particular, Case 376/96, Arblade and Others, 1999 ECR I -8453, Mazzoleni E ISA, 2001 supra note 53, Finalarte \& Others, 2001 supra note 56.
} 


\section{Legal Implications of the Pre-Accession Period}

\section{Economic Concerns and Diverging Practice of Legal Approximation}

In particular, it was argued that the enlargement is capable of diverting foreign direct investment from the EU-15 into the acceding states. ${ }^{66}$ Naturally enough, the popular expectation was a so-called 'displacement effect' for national workers based on a mistaken belief that the number of jobs in the economy is fixed. ${ }^{67}$ Another widespread fear is that a massive influx of workers from the EU-10 will lead to a dumping effect for wages (that rhetoric was especially efficient in the volatile days of Le Pen, Pym Fortuyn and Jörg Haider). ${ }^{68}$

'Wage effect' expectations were perhaps the most sound since wages in the CEEC (EU-8, i.e. with an exception of Malta and Cyprus) amounted only to 9\% of the EU15 average and the situation seemed to be especially vulnerable for particular industries (textiles and footwear), as well as for particular countries neighbouring with EU-10 (Germany, Austria). ${ }^{69}$

The economists used regional income differentials as the key variable in determining the probable scale of international labour migration. ${ }^{70}$ This approach showed that income differentials between EU-15 and EU-10 (and especially between EU-15 and EU-8) were, by no means, higher than those between Portugal and Greece, on the one hand, and the then member states, on the other hand. ${ }^{71}$

\footnotetext{
${ }^{66}$ Dougan, supra note 5, 133.

${ }^{67}$ Doyle, supra note $7,10$.

${ }^{68}$ Dougan, supra note $5,121$.

${ }^{69}$ Heather Grabbe, Profiting From EU ENLARgEMENT, 43 (2001).
}

70 Another trend is to concert wage levels at PPP (purchasing power parity). This approach shows that for some countries (especially Baltic States) the absolute gap in per capita incomes to the EU-15 is still capable of provoking large labour migration potential. For other countries (Slovenia and Czech Republic) PPP was quite comparative to the countries of previous enlargement. For a thorough economic analysis see Frigyes Ferdinand Heinz and Melanie Ward-Warmedinger, Cross-Border Labour Mobility Within An Enlarged EU, 52 OCCASIONAL PAPER SERIES, 16-17 (2006). For a more politics-oriented study see Marat Kengerlinsky, Restrictions in EU Immigration Policies Towards New Member States 2 Journal of European Affairs (2004). For detailed analysis of legal implications dating back to the economic fears see Orsolya Farkas and Olga Rymkevitch, Immigration and the Free Movement of Workers after Enlargement: Contrasting Choices 20(3) INT.J.CoMP.L.L.I.R. 369 (2004); Adelina Adinolfi Free Movement and Access to Work of Citizens of the New Member State: The Transitional Measures 41 CML REV. 469 (2005).

${ }^{71}$ Doyle, supra note 7, 121-122. 
Nonetheless, the experience of previous enlargements was rather a positive example since it demonstrated that the enlargement itself did not provoke significant disruptions for labour market and social standards of old member states.

Another debate which needs a brief overview with regard to its legal implications is the distinction between the aggregate and the regional impact of enlargement, since it was evident that neighbouring countries are far more likely to be flooded with migration..$^{72}$ Economic and statistical analysis revealed, in particular, that migrants often tend to choose a neighbouring country (being influenced by linguistic, cultural and transport fees considerations). On the other hand, old member states with English as the official language are more popular among migrants with high levels of education..$^{73}$ One more contradiction to the widespread beliefs is that European migrants, in fact, tend to be young, well-educated and single. ${ }^{74}$ Moreover, linguistic, cultural and social barriers, as well as high transaction costs of migration itself are usually capable of preventing the flood of migration. ${ }^{75}$ Economic analysis also concentrated on the so-called 'welfare magnets', i.e. on researching the hypothesis that migrants tend to pick up the countries with more sound welfare traditions. ${ }^{76}$ Perhaps, it was rather sensitive for such countries as Sweden or Ireland in their motivation to open labour market, but finally the research identified that 'welfare tourism' could hardly be a serious pull factor. In general, the social aspect was of particular importance due to another hypothesis, namely that organised crime and unscrupulous employees would be able to use social security system in order to keep wages costs down. The studies also demonstrated that an increased supply of labour may also induce new investments. ${ }^{.7}$ The latter is capable of counteracting wage decline, thus proving that 'benefit tourism' could only have limited consequences. In general, one could observe a spill-over effect ${ }^{78}$ in countries' motivation to open the markets with regard to social policy (especially in

\footnotetext{
${ }^{72}$ Dougan, supra note 5, 122.

${ }^{73}$ Doyle, supra note 7, 10.

${ }^{74} I d ., 20-21$.

${ }^{75}$ Dougan, supra note 5, 121-122.

${ }^{76}$ Doyle, supra note 7, 10.

77 Id., 19.

78 In other literature described as 'domino effect', see in particular, Samantha Curie, "Free" movers? The post-accession experience of accession - 8 migrant workers in the United Kingdom, 31 E.L. REV. 211 (2006).
} 
case of Ireland) since often the enlargement debate was much more concentrated on protecting the welfare system than on labour market issues. ${ }^{79}$

Economic analysis revealed that a small number of workers tend to migrate to old member states which shall not cause a long-term disruption of labour markets..$^{80}$ One of the most interesting economic arguments put forward not to postpone the enlargement was that business is already exposed to global competition and EU business can maintain profitability by using acceding Europe as a 'low-cost production site'.$^{81}$

Thus, one could conclude that the pre-enlargement fears provoked a specific socioeconomic debate which has proven that enlargement in itself is not capable to disrupt Western European labour markets as such but, on the other hand, it could have much more serious consequences for the neighbouring countries. This motivation line led to the legal consequences of imposing restriction period in the majority of EU states with particularly strong derogations for Austria and Germany. On the other hand, EU-15 also accepted certain concessions permitting the acceding states to introduce seven-year restrictions for the foreigners to acquire land in those countries. ${ }^{82}$

2. Transitional Arrangements and other Sage-Guard Measures: Implications for the Accession Treaty

The economic considerations demonstrated in the previous sub-chapter were echoed in the Act of Accession 2003 (Athens) by way of transitional arrangements. ${ }^{83}$ Interestingly enough, those arrangements dealt only with 8 acceding states (Poland, Hungary, the Czech Republic, the Slovak Republic, Slovenia, Estonia, Latvia and Lithuania) since Malta and Cyprus did not pose an evident problem for the labour market of EU-15. Old Member States were permitted to derogate from Articles 1-6

\footnotetext{
${ }^{79}$ Doyle, supra note 7, 23.

${ }^{80}$ Grabbe, supra note 69,4 .

${ }^{81} I d$.

${ }^{82} \mathrm{Id}, 14$.

${ }^{83}$ Kirstyn Inglis, Treading the Tightrope between Flexibility and Legal Certainty: The Temporary Derogations from the Acquis on the Freedom of Movement of Workers and Safeguard Measures under the Accession Treaty, in LA LIBRE CIRCULATION DES PERSONNES : ETATS DES LIEUX ET PERSPECTIVES, CAHIERS DU COLLĖGE D'EUROPE Nº 5, ACTES D’UN COLLOQUE ORGANISÉ EN 2003 À LIÈGE, (2007) 99-124.
} 
of Regulation $1612 / 68^{84}$, thus restricting in time the access to their labour market. This derogation was shaped in the so-called ' $2+3+2$ ' formula, i.e. old member states were permitted to restrict the principles of internal market with regard to labour vis-à-vis EU-8 following three-stage pattern: (1) from May 1, 2004 until April 30, 2006; (2) from May 1, 2006 until April 30, 2009 and, finally, (3) from May 1, 2009 until April 30, 2011. The third derogation is the most serious one since in order to justify itself it requires evidence of 'serious disturbances' or a 'threat of serious disturbances' for labour market (the so-called 'standstill clause').

Moreover, those states within EU-15 who already opened their markets could still invoke another provision (the so-called 'safeguard clause') which permits them to impose restrictions up until the ultimate terms if there is an evident threat of serious disturbances in their labour markets. This provision is especially interesting in the light of Laval since the proof could be based on the threat for the standard of living or the level of employment in a given region or occupation. That was the argumentation leitmotif of the Swedish government. Hence, theoretically social dumping could constitute a legal basis for this back-manoeuvre.

During the already completed first stage only three countries opened their labour market for EU-8, namely Sweden, Ireland and the United Kingdom. Upon the accomplishment of the first phase the Commission presented a Report on the Functioning of the transitional arrangements in the first phase which made some other countries follow open-labour model (Spain, Finland, Greece, Portugal and Italy) and yet more countries open their labour market only partially (Belgium, Denmark, France, Luxembourg and the Netherlands) ${ }^{85}$. Austria and Germany still keep on restricting their market. ${ }^{86}$ Upon accession of Bulgaria and Romania the model of graduality has now shifted to ' $1+2+1$ ' formula, i.e. the stages in opening labour market are now as follows: (1) January 1, 2007 until December 31, 2008; (2) January 1, 2009 until December 31, 2001, and finally, (3) January 1, 2012 until December 31, 2013.

${ }^{84}$ Regulation 1612/68 of the Council, of 15 October 1968, on freedom of movement for workers within the Community, OJL 257, 2-12.

${ }^{85}$ In Denmark labour market is fully covered, in Belgium, France, Luxembourg and the Netherlands flexible provisions cover only certain sectors or certain professions.

${ }^{86}$ Initially German and Austrian governments insisted on transitional derogations for certain sensitive sectors (e.g., construction, industrial cleaning, home nursing and security activities). This logic certainly dates back to consequences of the previous enlargements. Michael Dougan expressed an interesting opinion that the better alternative for Germany and Austria would be to require payment of their national minimum wage for posted workers from EU-8, despite the judgement in Mazzoleni. See Dougan, supra note 5, 138-139. 
As far as the recent enlargement from EU-25 to EU-27 is concerned, of the former EU-15 only Finland and Sweden totally opened their labour markets, which made, respectively, Viking and Laval to be the pioneer case-law in the field. France and Italy agreed to open their markets partially. The other countries (Austria, Belgium, Denmark, Germany, Ireland, Greece, Luxembourg, the Netherlands, Spain, Portugal and the United Kingdom) imposed restrictions. Among EU-10 only Malta restricted its labour market while Hungary imposed partial restrictions (getting a work permit depends on the sector). These cautions explain why so many governments submitted their observations before the Court in Laval. ${ }^{87}$ One could hardly stay impartial when the most essential issue of the European integration (free movement of the economically active population) is at stake.

It should be underlined that the transitional arrangements deal only with migrant workers from the newly accepted states. They do not allow old members to limit the free movement of other categories of the EU citizens (students or persons with independent means) ${ }^{88}$. Moreover, no derogation is possible once the worker had been legally employed for the first time in an old member state.

Hence, the key elements with regard to the labour market protection upon the enlargement are flexibility and graduality. ${ }^{89}$ The pre-enlargement debate embodied the joint venture of solidarity and conditionality ${ }^{90}$ in a legal telos of the accession acquis.

\section{Laval: a Clear Statement of the New Tendency?}

The approach of the Court is that neither economic nor social arguments are excluded but the crucial question is the one of balancing. The Court follows its traditional sufficient-derogation-test-analysis and recognizes the existence of the conflict without any reference to the affirmative support of the newcomers for the unity of the internal market (Para. 95, 108). Nevertheless, the Court emphasizes that the European integration is indeed not exclusively about providing the efficiency of

87 Austria, Belgium, Czech Republic, Denmark, Germany, Estonia, Finland, Ireland, Spain, France, Lithuania, Poland, UK. Even Norway and Iceland did not stay apathetic.

88 Communication from the Commission to the Council, the European Parliament, the European Economic and Social Committee and the Committee of the Regions - Report on the Functioning of the Transitional Arrangements set out in the 2003 Accession Treaty (period 1 May 2004 - 30 April 2006), COM (2006) 0048 final, 8 February 82006.

${ }^{89}$ Curie, supra note 78, 210.

${ }^{90}$ Marise Cremona, EU Enlargement: solidarity and conditionality, 30 E.L.REV. 3, 3-22 (2005). 
the economic freedoms. (Para. 104). The due respect should be paid to social rights. The question behind the judicial vocabulary is to what extend the decision is informed by social factors and a broader social context of the community legal order.

Horizontal effect is made applicable towards the trade unions but the particular benefits of this stance are vague. It is unclear whether the Court will keep on its iron logic of the internal market body-guarding, or whether in the future (where there is no conflict with the imposition of the EU norms on the national level) the horizontal effect has the potential to set up an actual derogation for the internal market, shaped into the social rights protection. Otherwise, it is not a big step for the recognition of the direct horizontal application since in judicial reasoning the trade unions could be easily substituted with the state authorities who do not undertake any efficient measures to stop the trade unions (the reasoning pattern of "Angry Farmers"91).

The notion of solidarity behind the lines acquires an extra value. Being traditionally regarded as a labor and social value, it encompasses a non-discrimination logic not only before (at the stage of the enlargement negotiation) but also after the enlargements. The implicit message from the Court could be formulated as follows: "The fear of social dumping is not an excuse to discriminate the eastward workers!" The internal market, thus, obtains an additional reinforcement in the context of the EU-27.

\section{Laval in the Context of Fundamental Rights}

\section{Evolution and Scope of Fundamental Rights in EC Law}

The status of fundamental rights in EC Law has for a long time been rather uncertain since initially the Community was established to pursue the goals of economic integration and did not presuppose a separate human rights policy. The situation is even more aggravated by the fact that on the European level there are at least two global systems of human rights observance with separate dispute resolution mechanisms, namely, national courts and national constitutional courts (on the level of states), and the European Court of Human Rights (on the level of the Council of Europe) ${ }^{92}$ In combination with a wide range of NGOs dealing with

\footnotetext{
${ }^{91}$ Case 265/95 Commission v. France, 1997 ECR I-443.

92 "Détriplement fonctionnel" as Prof. Douglas-Scott nicely phrases it. See Douglas-Scott, infra note 95, 639.
} 
human rights, this mechanism leaves small room for the EC manoeuvres in the field. Nonetheless, the evolution of the internal market revealed an over-whelming need to distinguish a separate human rights acquis in the Community. ${ }^{93}$ That policy required establishing a comprehensive legal ground for institutional decisionmaking and dispute-resolution with regard to fundamental rights in the ECJ. This uneasy task revealed several problems including delineation of the frontline between Strasbourg and Luxembourg, particular positioning of fundamental rights vis-à-vis economic freedoms in the Community and, what turned to be even a greater challenge, defining the scope of fundamental rights common for constitutional traditions of all member states. ${ }^{94}$ One could seriously doubt in the middle of the 1950s that European integration would reach these horizons, ${ }^{95}$ especially taking into account the fact that a separate jurisdiction in the field of fundamental rights was established on a pan-European level which turned to be a success story of Strasbourg.

This institutional contradiction founds its roots and reflection in the bulk of legal instruments which a relatively recently shaped EU citizen could invoke, in particular, national legal norms and principles (first of all, including those of constitutional character), European Convention on Human Rights and Fundamental Freedoms, and acquis communautaire including EU and EC Treaties. ${ }^{96}$

\footnotetext{
${ }^{93}$ One could argue that human rights steadily gained their importance from the late 1960s on (Armin Von Bogdany, The European Union as a Human Rights Organization? Human Rights and the Core of the European Union, 37 CML REv. 1307 (2000)). On of the first cases (often taken as a reference point) in which the Court explicitly refers to fundamental rights is traced back to the 1970s, namely Case 11/70, Internationale Handelsgesellschaft, 1970 ECR I-1125. Active reference to the case-law of Strasbourg started only in the mid 1990s. It is interesting to note in the context of present paper (tacking fundamentalization of social rights) that mere in the 1970s one could observe the recognition of social and labour rights in the decisions of the ECJ.

${ }^{94}$ For a profound analysis of the role of the ECJ in filling the empty box of fundamental rights in EC Law see Bruno De Witte, Le rôle passé et futur de la cour de justice des communautés européennes dans la protection des droits de l'homme in L'UNION EUROPEENNE ET LES DROITS DE L'HOMME 895-935 (Pilip Alston, Mara Bustelo and James Heenan (eds.) 2001). In particular, 905-920 (for a comprehensive evaluation of the Court's role vis-à-vis national systems, access to jurisdictions, degree of protection, etc).

${ }^{95}$ One could also recall declaration of the Charter of Fundamental rights, adoption of non-discrimination directives under Article $13 \mathrm{EC}$, and incorporation of human rights initiatives into policies such as the European Neighbouring policy (Cf., Sionaidh Douglas-Scott, A Tale of Two Courts: Luxembourg, Strasbourg and the Growing European Human Rights Acquis, 13 C.M.L. Rev. (2006). With regard to Article 13 EC in the context of European citizenship see also Catherine Barnard, Article 13: Through the Looking Glass of Union Citizenship in LEGAl Issues OF THE AMSTERDAM TREATY, 75 (David O'Keeffe and Patrick Twomey (eds.) 1999).

${ }^{96}$ For a detailed review see PIET EECKHOUt, EXTERNAL RELATIONS OF THE EUROPEAN UNION, LEGAL AND CONSTITUTIONAL FOUNDATIONS, 465-484 (2005).
} 
Nonetheless, the specification of that range of applicable acquis is important, first of all, for the internal purposes of the European Union where the progress of internal market is still a priority. The problem which demands a particular concern is whether one could observe a clash between economic (freedoms of movements) and fundamental (human rights) principles of the Community. ${ }^{97}$ This clash is analyzed as an interaction between the European Court of Human Rights and the European Court of Justice. ${ }^{98}$ The very analysis of this specific interface between the ECtHR and the ECJ has become a popular approach in the bibliography on judicial review of the ECJ since early 1990s. ${ }^{99}$ This is not surprising taking into account the peculiarities of the ECJ case-law which has constantly referred to the European Convention of Human Rights and Fundamental Freedoms. ${ }^{100}$

This specific reference to fundamental rights could also be found in other numerous domains of the EC law, in particular, with regard to free movement of persons ${ }^{101}$, competition law ${ }^{102}$, social and employment law ${ }^{103}$ etc. The latter is especially

\section{Trevor C. Hartley, European Union LaW in a Global ConteXt 332-352 (2004)}

${ }^{98}$ For a comprehensive description of the situations, where the ECtHR found jurisdiction over actions involving the EU, as well as about interaction between two courts see Douglas-Scott, supra note 95, 629665, (in particular, 632-639).

${ }^{99}$ See Francis G. Jacobs, Human Rights in the EU: the Role of the Court of Justice 26 E.L. REv. 331 (2001), Gráinne De Búrca, Fundamental Human Rights and the Reach of the EC Law 13 (3) O.J.L.S. 283-319 (1993), Rick Lawson, Confusion and Conflict? Diverging Interpretations of the ECHR in Strasbourg and Luxembourg, in THE Dynamics of the Protection of Human Rights IN EuRope 219 (Rick Lawson and Matthijs de Bloijs (eds.) 1994), and D. Spielman, Human Rights Case Law in Strasbourg and Luxembourg Courts: Inconsistencies and Complementarities, in PHILIP ALSTON (ED.), THE EU AND HUMAN RIGHTS 770 (1999).

${ }^{100}$ In recent literature among other ways-out the following ones were proposed: (1) a solution "à la Keck" (with an interesting parallel to the revolutionary limits established by the Court in case Keck $\mathcal{E}$ Mithouard, 1993, supra note 28), (2) introduction of de minimis rule (exclusion from application of human rights derogation in the situations when no significant economic effect is evident), (3) "Cassis de Dijon solution" (with reference to Case 120/78, Cassis de Dijon, 1979 ECR I-649, where the Court elaborated a compatibility test on the basis of the restrictive effects' analysis under Article 28 EC escaping from the derogation of Article $30 \mathrm{EC})$. See Alberto Alemanno, Á la recherche d'un juste équilibre entre libertés fondamentales et droits fondamentaux dans le cadre du marché intérieur: quelques réflecions à propos des arrêts " Schmidberger » et « Omega », RDUE 4/2004, 709-751 (2004).

101 Especially with regard to the discussion on the role of Article 6 ECHR which often affects the third countries nationals. Cédric Chenevière, Régime juridique des ressortissants d'Etats tiers membres de la famille d'un citoyen de l'Union, in LA LIBRE CIRCULATION DES PERSONNES: ETATS DES LIEUX ET PERSPECTIVES, CAHIERS DU COlLEGE D’EUROPE N 5, ACTES D’un COLLOQUE ORGANISE EN 2003 A LIEGE, (2007), 125-144.

102 Sybe De Vries, Public Service, Diversity and Freedom of Expression and Competition Law, ERA, 1/2005, 4657 (2005).

103 Prechal, infra note 111. 
interesting in the context of the present article since it shapes the ground of the discussion on the fundamentalization of social rights'.104

In order to discuss the potential for this fundamentalization of social rights, we need to identify the very legal grounds for fundamental rights in the Community legal order. Nowadays within (and even outside) the EU one could distinguish, at least, eight platforms to protect fundamental rights which are as follows (infra these sources will be exemplified with the models of judicial reasoning in Laval):

- Article 6 (Par. 1-2) EU with a reference to fundamental rights as guaranteed by the ECHR and constitutional traditions common to the Member States, as general principles of Community law (amicus curiae submissions)

- Article 13 EC (on non-discrimination) ${ }^{105}$

- The established case-law of the ECJ (especially with regard to a situation of a clash with the internal market)

- Human rights as an inherent part of constitutional traditions of member states (ius commune of human rights ${ }^{106}$ )

- Judicial dialogue between ECJ and ECtHR (mostly by way of preliminary rulings)

- General acceptance of International Human Rights Law (it is the EU which promotes the instrumentalization of human rights under political frame of the UN)

- The mechanism of human rights clauses vis-à-vis third countries

- Charter of Fundamental Rights ${ }^{107}$

The Charter is a unique mechanism merging two freedoms, namely fundamental (human rights) and social (including labour) ones. The implicit question brought by Laval is whether one could observe the emergence of social human rights and which implications it could produce in the transitional (post-accession) context where social rights represent another clash with the internal market.

\footnotetext{
${ }_{104}$ Philip Alston, Labour Rights as Human Rights, The Not so Happy State of the Art in Labour Rights as Human Rights, Volume XIV/1, OUP, 2006, 1-24. Also, Regina Kreide, The Range of Social Human Rights, 18 GLJ (2001), available at: http://www.germanlawjournal.com/article.php?id=116 (last accessed on 18 November 2008).

105 Barnard, supra note 95.

106 Douglas-Scott, supra note 95, 665.

107 The EU Charter of Fundamental Rights of the European Union, O.J. 2000 c 364/01.
} 
EC Social Law is the domain which has been even more influenced, if not outright created, by the Court than freedom of movement under the internal market. The decision-making process in the EC has been consistently reflecting the reluctance of particular states to broaden EC powers to harmonize the domain of labour and social relations. This is an extremely sensitive area since, on the one hand, social and labour models in Europe differ significantly, and on the other hand, amendments in the sphere of social and employment rights lead to a risk of essential financial losses for particular states. ${ }^{108}$ Recent trends in the area of social policy demonstrate an "increase in the use of complementary or rather alternative methods of regulation to the Community Method"109 which leads to a 'transverse form of policy making'. ${ }^{110}$

In fact, it was the ECJ who has been giving impulses for harmonisation of working time, parental leave, equal opportunities, and mechanisms of social dialogue.111 Another trend is a so-called soft acquis, which reveals a shift from legislative initiatives towards policies aimed at fostering employment creation, social protection and social inclusion. ${ }^{112}$

Art. 137 (Par. 4) EC sets limitations for the uniform labour standards with an effect that harmonization, holding that standards "shall not affect the right of Member State to define fundamental principles of their social security systems and must not significantly effect the financial equilibrium thereof;" and "shall not prevent any Member State from maintaining and introducing stringent protective measures compatible with EC Treaty."

\footnotetext{
108 For a detailed analysis of the stages in the development of social and labor rights in EC Law see Stefano Giubboni, SOCIAL RIgHTS AND MARKET FREEDOM IN THE EUROPEAN CONSTITUTION: A LABOUR LAW PERSPECTIVE (2006).

109 Samantha Velluti, The European Employment Strategy and the Challenges of Enlargement in TAKIS TRIDIMAS (EDS.), EU LAW FOR THE 21 ${ }^{\text {st }}$ CENTURY: RETHINKING THE NEW LEGAL ORDER 415-436 (2004).

${ }^{110} \mathrm{Id}$.

111 Sasha Prechal, Equality of Treatment, Non-Discrimination and Social Policy: Achievements in Three Themes, 41 CMLRev. 533, 533-551 (2004); Bernard Ryan, The Private Enforcement of European Union Labour in THE FUTURE OF REMEDIES IN EUROPE, 141, 141-147 (Claire Kilpatrick, Tonia Novitz and Paul Skidmore (eds.) 2000); Eugenia Caracciolo Di Torella and Annick Masselot, Pregnancy, Maternity and the Organization of Family Life: an Attempt to Classify the Case Law of the Court of Justice 26 E.L.REV. 239, 239-260 (2001); Lisa Waddington and Mark Bell, More Equal Than Others: Distinguising European Union Equality Directives 38 CMLREV. 587, 587-611 (2001).

112 Velluti, supra note 110.
} 
Moreover, the Community lacks competence in harmonizing the right of association, the right to strike or the right to impose lock-outs ${ }^{113}$, which (as we shall see infra) has an implication for safeguarding national social standards upon enlargement.

\section{A Clash Similar to the Effects of Fundamental Rights?}

The eastward enlargement revealed that the danger for labour markets of EU-15 lies not obviously in the influx of workers from CEEC but rather in the difference in wages, social standards and systems of labour relations in the West and East of Europe. The 'social dumping' is the term which is acquiring broader recognition both in doctrine and in the judgements of the Court.

Two other factors suggest that things could have been otherwise. First is that collective bargaining seems to be the popular direction of activity coordination at the EU level. ${ }^{114}$ Second is that the Charter is arguably enjoying a potential to break new ground by incorporating social and economic rights (including the collective labour rights ${ }^{115}$ affecting the laws of Member States on trade unions ${ }^{116}$ ) into the realm of fundamental rights.

Notwithstanding these arguments, in Laval the Court sets out a traditional internal market test, where social rights motivation of Swedish trade unions does not pass the proportionality assessment. The Community enjoys a limited competence to pursue harmonization in the social sphere since Article 137 EC specifically excludes harmonization of national wages from the Community's competence over social policy and Article 95 EC does not apply to employment matters. ${ }^{117}$ Thus, the field for fundamentalizing manoeuvre is restricted. Another way to interpret this ambiguity is to claim that precisely because the harmonization in the field is impossible, the Member States are free to safeguard their social policy traditions, thus limiting the potential for the intervention both from Brussels and Luxembourg. The Court, however, does not seem to approve such a stance. Par. 88

\footnotetext{
113 Anne Davies, Should the EU Have the Power to Set Minimum Standards for Collective Labor Rights in the Member States? in LABOUR RigHTS AS HuMAN RigHTS, 177-213 (Philip Alston (ed.) 2006).

${ }^{114} I d ., 316$.

115 Davies, supra note 113. Cf. also Erika Kovacs The right to strike in the European Social Charters, 26 COMPARATIVE LABOUR LAW \& POLICY JOURNAL, 445, 445-475 (2005).

${ }^{116} I d ., 321$.

${ }^{117} \mathrm{Id}$.
} 
explicitly states that "[...] the fact that Article 137 EC does not apply to the right to strike or to the right to impose lock-outs is not such as to exclude collective action such as that at issue in the main proceedings from the domain of freedom to provide services".

Although the Advocate General thoroughly analyzes the current stance of the ECtHR with regard to industrial actions (Gustafsson $v$. Sweden and Sørensen $v$. Rasmussen) ${ }^{118}$, the Court is not inclined to go into the detailed comparative study of Strasbourg's case load. Nevertheless, the decision in Laval can be implicitly informed by the latter, considering that both main ECtHR cases originate from Scandinavia with its particular trade unions' status. Moreover, in those two cases Strasbourg took a manifest support of the negative right to association, i.e. the right of an employer not to be forced into a collective bargaining agreement. Thus, ECJ contributes to the "fight" against Nordic model of industrial relations, characterized by such features as self-regulation, non-intervention and wide autonomy of social partners.

Another ambiguous question steps from the hypothesis that if Sweden transposed the Posted Workers Directive with the acceptance of the minimum wages model, the outcome of Laval could have been different. In this sense, Laval is not the hardest nut for the ECJ who managed both: to proclaim that the EU integration is not only about economic efficiency ${ }^{119}$ and simultaneously to safeguard the sanctuary of economic freedoms ${ }^{120}$. The argumentation of the court is based on the wages calculation and not on balancing social rights versus fundamental freedoms stricto sensu.

Nonetheless, even if presuming that such hypothetical situation checks out, I doubt if the decision could be different. In order to bring the social rights (in particular, the right to industrial action) into the realm of fundamental rights derogations, the Court will need either to establish a sound link with Strasbourg (as it has been demonstrated supra, such manoeuvre is hardly possible) or to address the

\footnotetext{
118 Para. 275, 303 in the Opinion of AG Mengozzi (Eur. Court H.R., Gustafsson, Judgement of 25 April 1996, Report of Judgements and Decisions 1996-II; Eur. Court H.R., Sørensen v. Rasmussen, Judgment of 11 January 2006, unreported). In para. 302 AG discusses another Strasbourg case in the context of the overpowered Swedish trade unions (Eur. Court H.R.., Evaldsson and Others v. Sweden, Judgement of 13 February 1996, Application no. 75251/01).

119 Para. 104, 105 (social purpose of the Community), para. 91 (the right to take a collection action is indeed a fundamental right as a general principle of EC Law).

120 Para. 108 (the obstacle at stake cannot be justified by the social purpose), para. 95 (collective action should be balanced against the internal market).
} 
constitutional traditions of 27 Member States where the recognition of social rights differs tremendously. Following the other bases identified in the previous subchapter for fundamental rights, Article 13 EU should rather suggest a nondiscrimination logic against Swedish trade unions who block the pursuit of the economic freedoms for the foreigners. The right to collective action is, above all, not boundless. To give an example, it is hardly legitimate to raise it, for instance, to prevent racial minorities or women to work at a certain enterprise. The established case law will suggest the path of Schmidberger to which Scandinavian commentators implicitly tended to compare Laval when awaiting for the decision. ${ }^{121}$ However, the pattern of the aggressive protest (with the total blockage towards the exercise of fundamental freedoms) rather fits the logic of "Angry Farmers" in France.122 Similarly to the French case, the police are asked to intervene but they refuse on the ground of the constitutional protection for the collective action.

However, one could arguably state that the constitutional safeguard of bargaining model in Scandinavia is a part of the constitutional tradition comparable to the status of human dignity in German Grundgesetz, thus linking the case to Omega ${ }^{123}$. This line is the most controversial since the differentiation of what constitutes a constitutional tradition, i.e. what deserves the Community protection, is highly problematic. The comparison here lacks explicit legal grounds.

The Court does not swim deep to those numerous cavities, avoiding the fundamentalization of social rights complexity. The implicit reasoning of Laval is informed by the post-enlargement context. The ECJ produced a judgement whose main goal is to confirm as firm as possible the sanctuary of the inviolability of the economic freedoms, thus, protecting the rights of the workers from the newly acceded states against the discrimination. As it has been demonstrated previously, the opening of the internal market(s) is a gradual process where the EU-15 enjoy quite a few relieves. The Court does not seem willing to broaden those privileges which have already put the new-comers into not exactly equal positions.

\footnotetext{
${ }^{121}$ Ahlberg, Bruun and Malmberg, supra note 1. In particular, 163-164 (the reasoning pattern is to frame the right to strike into a public policy derogation to free movement of services, strong enough to pass the proportionality assessment). Thus, the authors hastily predicted that the Swedish model will not be endangered.

${ }^{122}$ Further the juxtaposition is done to Commission v. France, [1997] supra note 91.

${ }^{123}$ Case 36/02 Omega, 2004 ECR I-9609. The Court refers to Omega briefly in para. 93, 94 of Laval.
} 
The position of the Court is definitely not accidental. The very recent case Dirk Rüffert $v$. Land Niedersachsen ${ }^{124}$ in the German-Polish context confirmed the logic of non-admissibility of the wage imposition (through "contractual" legislation at the case of Lower Saxony) which could impede or render less attractive the provision of services by workers from the new member states.

\section{Conclusions: a Step Back - a Step Forward. Paving the way for the Fundamentalizaion of Social Rights}

The enlargement created a unique moment for the ECJ to display the status of the social rights in the Community order, since it brought into judicial agenda a hardnut which the Court has been quite reluctant to shell so far. Namely, the enlargement articulated the problem of social rights vis-à-vis the internal market. ${ }^{125}$ The question is whether social rights are capable of creating derogations similar to those established by fundamental rights.

The first part of this article demonstrated that the internal market provisions on free movement have undergone a revolutionary circle of development where the ECJ has been filling the empty box of EU citizenship with a wide spectrum of legal benefits. The preservation of the internal market interests in Laval perfectly fits the case-law pattern of Luxembourg. On the other hand, it became evident that the scope of social rights has also been expanded by the Court to the horizons one could hardly expect half a century ago. Nonetheless, the status of particular social rights (as the right to industrial action) in Community law is rather unclear.

The pre-accession economic fears made the majority of the EU-15 adopt limitations for the access of labour from CEEC. The key word in that system of limitations is graduality. Old member states negotiated the plan of gradual opening of their markets to avoid serious disturbances. Sweden became one of the countries who fully opened their labor markets for the service providers from the EU-10. As time has shown, the potential disturbance for the labour markets of EU-15 lays not in the danger of massive influx of workers from the newly accepted states, but rather in

\footnotetext{
${ }^{124}$ Case 346/06 Dirk Rüffert v. Land Niedersachsen, 2008. In para. 42 the Court states: “[...]it does not appear from the case-file submitted to the Court that a measure such as that at issue in the main proceedings is necessary in order to avoid the risk of seriously undermining the financial balance of the social security system, an objective which the Court has recognised cannot be ruled out as a potential overriding reason in the general interest".

125 See Manfred WEISS, Enlargement and Industrial Relations: Building a New Social Partnership, 20 INT.J.COMP.L.L.I.R. 5 (2004).
} 
differences of labour costs and social standards. This problem is acquiring a wider recognition under the term of 'social dumping', virtually recognized by the ECJ. In Laval the Court framed the industrial action into the framework of a possible derogation which turned to be disproportional when balanced with the purposes of the internal market. Nevertheless, the ECJ pronounced explicitly on the potential of social rights to be perceived as fundamental rights under the general principles in the EC Law.

Hence, Laval is indeed an evasive indicator of the fundamentalization of social rights. However, I could hardly share the opinion that Laval significantly undermined the position of social rights in Europe. Careful analysis of the "blockage" situation reveals that the ECJ is actually consistent with the reasoning of the ECtHR. Implicitly following Strasbourg, the ECJ sets a lesson for the modification of the Nordic industrial model and limits the tyranny of trade unions. "Good manners" are imposed through the non-discrimination logic of the European integration. The arbitrariness of the wage calculation by social partners is an aspect which does not enjoy the cover of fundamental social rights.

The Court delicately avoids the rhetoric of the post-enlargement solidarity; however a deeper insight into the pre-enlargement negotiation reveals an implicit motivation of the Court. The sanctuary of economic freedoms as the foundation of European integration is reinforced in the context of the EU-27. Old member states have negotiated the graduation system as a pill against social dumping. The Court does not permit further fragmenting of the internal market through social provisions as a charlatan charter for the back-manoeuvre against the EU citizens ${ }^{126}$ from the new member states.

The decision in Laval has significant legal, financial and demographic implications both for old and new member states.

Firstly, as far as a graduality system of market opening is concerned, the decision could either give impetus to final liberalization vis-à-vis CEEC or slow down the process, especially in Germany and Austria.

\footnotetext{
${ }^{126}$ Similarly Moreau induces the progress of 'fundamental social rights' from the perspective of "citizenworkers". She demonstrates that the internal market is actually structured by social rights, including the right to collective bargaining. Marie-Ange Moreau, European Fundamental Social Rights in the Context of Economic Globalization, in SOcIAL RigHTS IN EUROPE (Gráinne De Búrca and Bruno de Witte (eds.) 2005), esp. 370-371. In Laval the Court tackles the abuses of such structuring.
} 
Secondly, the Nordic model of salary bargaining is proclaimed contradictory to the EC Law as far as it applies to the service providers from other member states. One way out for the Swedish government is to reform radically the whole system which forms an essential tradition of labour relations in this country. Alternatively and most probably, it could keep an old system of the wage bargaining for the pure internal situation and change the rules vis-à-vis the external EU-based context. The major form of the judicial activism is the limitation of the trade union omnipresence. Notwithstanding the fact that a horizontal direct effect applies to them, the trade unions are prohibited to substitute the state. The burden of proof is also set on trade unions.

Thirdly, Laval indicates a strong impulse for the EU to keep on developing clear rules in the social sphere through the harmonization instruments. Otherwise a purely political failure to reach the compromise goes to the ECJ for which economic freedoms are obviously holy commands.

Fourthly, it may change the strategy of the old member states in the period of the future EU enlargements. The situation gives an incentive to negotiate an averagesalary-protection-clause into the accession instruments.

Fifthly, the decision contributes to a further-migration-encouragement effect. The populist claim will be to question whether this stance shapes a "second sort of $E U$ citizenship" - ready to work for the indecently minimum salaries. Around 70000 people have already left two-million Latvia ${ }^{127}$. Thousands people have been leaving one-million Estonia for labour migration. Not to mention a huge work migration from Lithuania or 1.5 million of Polish workers in the EU-15.

Sixthly, in the context of the British opt-out from the Nice Charter a decision alleviates the anxieties of the British government that further "labour and social law integration" is capable to enforce a union authoritarianism into the UK legislature. The Court avoids explicit references to the Nice Charter. Social rights seem to be imposed on the UK in full effect without regard to the Charter - as the fundamental rights inherent to the general principles of the EC Law.

127 There are symptoms that Latvia itself experiences the lack of the construction workers due to the mass influx of the population to the EU-15. Also, see Migration and the Latvian Labor Market at http:/ /latviaeconomy.blogspot.com/2007/08/migration-and-latvian-labour-market.html (last accessed on 18 November 2008). 
Hence, in the Luxembourg gallery of the fundamentilization canvas Laval decision is portrayed as a dance pavilion with the pan-European media audience. The distinguished judges make un pas en avant, accepting the fundamental status of social rights. Then they elegantly step back, giving a bow of respect towards the EU-27 internal market and teach trade unions a lesson of good behaviour on the dance floor. The tango continues. 
